\title{
Pancasila as the Establishing Ideology of Nationalism Indonesian Young Generation
}

\author{
Nuzon Sugito ${ }^{1, *}$, Ratu Aulia ${ }^{2}$, Lisa Rukmana ${ }^{3}$ \\ ${ }^{1}$ History Education Study Program, School of Postgraduate Universitas Pendidikan Indonesia, Bandung, Indonesia \\ ${ }^{2}$ Civic Education Department, School of Postgraduate Universitas Pendidikan Indonesia, Bandung, Indonesia \\ ${ }^{2}$ History Education Study Program, School of Postgraduate Universitas Negeri Yogyakarta, Yogyakarta, Indonesia \\ "Corresponding author. Email: nuzonsugito@upi.edu
}

\begin{abstract}
The Indonesian as a nation cannot avoid the challenges of globalization in all spheres of life, but by sticking to the values of the Pancasila as the guiding principles of the Indonesia Country will be able to survive facing the times, because everything has been regulated in the philosophy of Pancasila. This article argues that while maintaining the spirit of nationalism, in the younger generation mindset through the Citizenship Education $(\mathrm{PKn})$, it will be make them survive from negative influences and moral impairment in an era where globalization is uncontrollable, the influence of foreign cultures that able to make young people easily leaving their own culture because they consider foreign cultures more modern than Indonesian Cultures. Thus, Civics Education is very important to strengthen the morality and ethics of the younger generation, besides that a persuasive approach and dialogue to the public about the importance of Pancasila as the state ideology will make them better to face globalization and defend Indonesia's identity.
\end{abstract}

Keywords: Pancasila, Ideology, Young Generation, Nationalism

\section{INTRODUCTION}

Ideology is the most basic thing that will determine the direction and goals of a country, in the context of the wider community ideology is often used as a basis in efforts to free human minds, as Setyowati [1] argues that ideology is a set of ideas that guides a group of people in achieving a goals, in general ideology is in the form of theories that are not oriented towards truth, but in the interests of those who propagate it [2]. Ideology is categorized into two types, namely open ideology and closed ideology. Closed ideology not only determines basic values and principles, but arrives at something concrete and operational, on the other hand open ideology contains basic orientations while its interpretation depends on the moral principles that develop in society. An example of a closed ideology is communist ideology, this ideology is the result of the thoughts of Karl Marx as in the Soviet Union, while an example of an open ideology is the Pancasila ideology adopted by the Indonesian state.

As an open ideology, Pancasila is flexible, meaning that Pancasila is an ideology that can adapt to existing conditions without having to change the essence of the standard values contained therein, Pancasila is an idea or theory whose truth is believed to be a way of life for the Indonesian nation that is used to solve each existing problems, Pancasila also always provides solutions to every problem that exists in Indonesia. Pancasila has been the consensus of Indonesia's founding fathers since August 18, 1945, which reads: 1) Believe in the one supreme God, 2) Justice and civilized humanity, 3) The unity of Indonesia, 4) The democracy led by understanding wisdom among honorable representatives from the parliament house, 5) Social justice for all of the people of Indonesia. As a solution for Indonesian citizens, Pancasila should have pervaded every citizen, practiced properly the values contained in it so that there will be no problems that cannot be resolved, this also applies to holders of power and policies who are positioned as role models, both old and young.

According to Law (UU) Number 40 of 2009 concerning Youth, youth are Indonesian citizens who have entered an important period of growth and development, who have ages ranging from 16 years to 30 years who are characterized by enthusiasm, critical nature, idealism, innovative, progressive, dynamic, and reformist [3]. However, seeing the current condition of youth, it is fitting that we turn the pages of history, how the youth of this great nation build nationalism so that they are able to escape the colonialization of foreign nations, however, we must also see that the mistakes of the past also show Pancasila to be a political commodity, thus making some Indonesian people become antipathy to Pancasila. According to Tribun News Jogyakarta, as many as 20 percent of Indonesia's younger generation who do not memorize Pancasila as the basis of the state, which is very simple but full of meaning [4], and most Indonesian 
citizens who do not memorize Pancasila are in the province of Bangka Belitung [5]. On the other hand, a survey from the Ministry of Home Affairs (Kemendagri) states that 50 percent of Indonesians do not memorize the national anthem of Indonesia Raya [6] while for the younger generation based on a survey 80 percent of school children also do not memorize the song "Indonesia Raya" [7]. Lowethal (1994) explains that something that makes a symbol of identity or an icon of a country, one of which is the national anthem, it can be said that if we do not remember in detail the symbols of our country (Indonesia Raya \& Pancasila) then we are included in the category of people who do not have nationalism [8]. The decline in nationalism was also caused by uncontrolled globalization that entered Indonesia. Sundawa [9] argues that the flow of globalization that has a negative impact and becomes a threat can be in the form of the spread of new ideas, especially from the West (westernization), moral degradation, changes in mindset to materialism, and unlimited freedom (liberalism). Globalization causes clashes between local cultures and free cultures from other countries outside Indonesia. In addition, at the level of the younger generation, it can be seen that many are already oriented towards external cultures which give rise to the perspective that outside culture is more modern than their local culture, this can be seen from their enthusiasm to change attitudes, ways of speaking, appearance (fashion) and even life patterns. Even though youth have a role as social control which should have a strong nationalism and understanding of Pancasila as the foundation that forms nationalism.

Furthermore, according to Azra, Pancasila is marginalized and difficult to develop today due to three factors, First, Pancasila has been polluted due to the policies of the new order regime which made Pancasila a political tool to maintain the status quo of its power; Second, political liberalization with the elimination of the provision that Pancasila is the only basis for organizing, the enactment of this provision automatically opens opportunities for other basic foundations to become organizational principles, such as religion, etc., this causes Pancasila to no longer be the only basis. in national and political life; Third, the issuance of decentralization and regional autonomy policies. This policy has more or less impact on strengthening regional sentiment which automatically increases chauvinism in the regions and eliminates nationalism towards Indonesia [10]. The purpose of this article is to offer a small number of therapies to our sick country, with how the younger generation can re-absorb Pancasila and the National Anthem of Indonesia Raya in an effort to restore nationalism to the nation, such as during the Rengasdengklok incident, or during the youth pledge in 1928.

\section{METHOD}

The approach used in this study is a qualitative approach. as stated Creswel qualitative research is a research process by exploring problems and developing a detailed understanding of central phenomena [11]. Qualitative means something related to the aspect of measuring the quality, value or meaning contained in a fact or phenomenon. These qualities, values or meanings can only be expressed and explained through words. The research method used in this research is descriptive method which is carried out by analyzing the factors related to the object of research by presenting more indepth data on the object of research [12]. This research was conducted by looking for data relevant to the discussion of Pancasila as the ideology that forms the nationalism of Indonesia's young generation. After the data is obtained, the researchers interpret and analyze these data to produce in-depth ideas about the object of study.

\section{RESULT AND DISCUSSION}

\subsection{Pancasila as the establishing ideology of nationalism Indonesian young generation}

Pancasila as the Indonesian ideology is a political consensus made by Indonesia's founding fathers [13][14][15]. Pancasila promises a commitment to unite in attitudes and views, to build the country without questioning differences in background, culture, religion, race, ethnicity and language [16] so that national goals can be realized [17].

Pancasila has differences with the capitalismliberal and socialism-communist systems. These differences make Pancasila superior to other systems because Pancasila recognizes and protects individual rights and community rights both in the economic and political fields. Thus the Pancasila ideology harmoniously recognizes both the collectivism that exists in the communist system and the individualism that exists in the liberal capitalist system [2]. In the definitive formulation of Pancasila, it is arranged hierarchically and synergistically according to its position as the state philosophy and the basis of the state which adheres to the sovereignty of the people, populism as a consequence of the pluralistic Indonesian nation [18].

Historically in Soekarno's speech on June 1, 1945, it indirectly gave rise to Pancasila as the Philosophy of Grondslag, when Pancasila had different editors, namely the basis of nationality, the basis of internationalism, the basis of representative consensus and deliberation, and the basis of welfare and the basis of divinity [16]. Meanwhile, according to Sundawa (2016) Pancasila is rich in the noble values of Indonesian culture wrapped in democracy [15][19]. In the era of the industrial revolution 4.0 , it is very important to maintain the existence of the personality of the Indonesian people, this is because the flow of information is very fast which is also accompanied by the very fast entry of foreign cultures as well. Indeed, the development of information technology also has a positive effect, including making it easier for young people to get 
data and information and facilitating long-distance relationships, so that between countries there are no barriers, but also globalization is able to divert the values of Pancasila which can lead to disintegration of the nation and of course will trigger conflict in the community, especially in the younger generation, according to Law Number 40 of 2009 as an unstable and excited human being [3].

Pancasila is the foundation of the Indonesian state as well as an ideology that is full of tolerance and pluralism [13] This is because Indonesia is a multicultural and pluralistic country built on differences in ethnic, cultural, religious and ethnic backgrounds. This unity will not be realized if it is not accompanied by a sense of nationalism from every citizen. If we examine Pancasila, it is in accordance with the conditions of this country according to its era, as in the first principle of Pancasila "Believe in the one supreme God", contains awareness of divinity, this is because Indonesia as a country that holds tightly to religion as an Indonesian identity [20]. The first point in Pancasila is a representation of the diversity of beliefs that are not limited in Indonesia, starting from prehistoric times, our ancestors already embraced animism and dynamism, indirectly acknowledging that they are weak and glorifying something above them, which includes belief in various trees., belief in wild animals and ancestral spirits. This continued in the Hindu-Buddhist belief in Indonesia which became very large during the era of the Srivijaya Majapahit kingdom, as well as the Christian belief that developed in the Tapanuli region and some eastern parts of Indonesia in the century 16 and above and accompanied by the entry and spread of Islam, from this pluralism Pancasila is able to protect it, Indonesia is inclined towards one of the religions in recognition of Indonesia's pluralism, according to Meinarno [21] that there is a connection between transcendent character and the first principles of Pancasila, dim This divine value is based on tolerance between religious communities, if the values of this principle are implemented properly, Indonesian nationalism will form by itself.

Furthermore, the second principle is "Justice and civilized humanity", which means that humanity is the main point in this principle, the second principle focuses more on the character of Indonesian citizens who emphasize noble morals or behavior and have a noble attitude among citizens. This explains that the Indonesian nation as a civilized human being upholds justice, is not only selfish, respects and appreciates fellow human beings. Human values in the second principle also have a connection with divinity and religion that develops in Indonesia [20]. Indirectly, the Indonesian founding father thought deeply and had considered that common interests, humanity and justice were the characteristics of Indonesia, so that if the second principle was properly inspired by the younger generation, a strong nationalism would automatically form itself.

Whereas in the third principle, "The unity of Indonesia", the sentence which is in short editorial, contains a lot of meaning. The concept of unity is formed from the spirit of humanity demanding togetherness among communities spread across Indonesia [20]. It was clear that the founders of this nation wanted to show that without unity there would be nothing Indonesian. Because at that time it was unity which became a tool to escape from colonialism and oppression. So that the unity and integrity of Indonesia are mandatory for Indonesia to maintain its existence as a country and as a country that has a plural and multicultural society, with different ethnic, linguistic, cultural and religious backgrounds. One of the efforts is to create a unified language, namely Indonesian. This third point directly explains that the younger generation must unite in the same spirit of nationalism as the spirit of the youth oath of 28 October 1928.

Then, in the fourth principle, namely "The democracy led by understanding wisdom among honorable representatives from the parliament house", this sentence shows that the Indonesian people must have a sense of responsibility and harmony in every decision made by the people's representatives who sit in the People's Representative Council (DPR) through deliberation for the benefit of all. According to Morfit (1981) "musyawarah" means "which means deliberation and discussion among society,.... And implies the will be Majority dominance or minority tyranny "[14]. This means that the key to deliberation is to consider all levels of society so that there is no domination between the majority and minority groups, this deliberation is what distinguishes Pancasila democracy from western democracy. According to Sitorus (2016) "Kerakyatan" in the shade of democracy strengthens all elements that make humans more humanistic, such as the characteristics of Indonesians [20]. So that if the younger generation internalizes this fourth point, it will increase their sense of nationalism, because every decision is made based on mutual agreement and benefit.

Finally, the fifth principle, which reads "Social justice for all of the people of Indonesia", implies that as citizens we have rights and obligations, the concept of social justice where every citizen gets an equal share of intellectual, spiritual and state property. , which is managed by the state's representatives in the government, so as to create a dynamic balance according to the needs and situations. If this is absorbed properly by the younger generation, the sense of nationalism will grow by itself, because common interests and shared pride are the keys to nationalism.

Benedict Anderson stated that nationalism is an idea from society or community. Nationalism can be interpreted as "Imagined Communities" which means a thought that is imagined by every human being in a nation as a social identity, this image is based on concepts such as ethnonationalism or cultural nationalism which views humans as inherently organized into historical communities as having their strength and uniqueness as well as cultural peculiarities based on local values [22]. In a narrow sense, nationalism is an attitude that exalts the nation and state itself, in the context of Indonesia which has the ideology of Pancasila, nationalism is defined as a 
view that shows the love of every citizen for his nation and homeland which is based on the noble values of Pancasila [23].

Nationalism grew together from the sense of equality and togetherness of the Indonesian people during the colonial era to create the Unitary State of the Republic of Indonesia (NKRI). Regarding nationalism, it is actually not a new phenomenon, because if we look at history, the concept of nationalism originates from the concept of nation and state, in Europe it only appeared in the 18th century. Nationalism is a thought formed from a wave of populist revolution that brings the spirit of egalitarianism to overthrow the hegemony of the aristocratic class. Nationalism in Indonesia cannot be equated with nationalism in western countries, this is because Indonesian nationalism has a life of justice and anticolonialism [22]. In terms of growth and development of nationalism in Indonesia, Latief (2015) divides it into two, the first is ancient nationalism (Archaic Nationalism) and old nationalism (Proto Nationalism) [23]. Ancient nationalism (Archaic Nationalism) appeared simply and followed the political opportunity structure made possible by the colonialism regime, this nationalism was locality although at some level it could mutually influence with the ideology formed in other parts of Indonesia. Meanwhile, old nationalism (Proto Nationalism) is a nationalism that is more organized because of the emergence of national social movements. Of the two types of Indonesian nationalism, related to the participation of youth in their era, where in ancient nationalism, youth participated in fighting in expelling the Portuguese in Ternate under the Command of Sultan Babullah, as well as in the old nationalism era, how the young generation at STOVIA had the idea to establish an organization Budi Utomo, or how could the youth exile Soekarno to Rengasdengklok to ask for the proclamation of Indonesian independence to be accelerated.

However, this nationalism cannot grow perfectly in today's era where there is no threat of physical colonization anymore, so it requires a new alternative, especially in this modern era. Mahpudz has the view that building nationalism at the level of the younger generation can be realized through Citizenship Education (Civics) which can create a feeling of coincidence which is able to form concern and sensitivity to problems facing the nation, including problems that are related to a sense of solidarity with the nation and country [24] . Because youth actually have the responsibility to participate in national development, one of which is like maintaining the integrity of the Republic of Indonesia, strengthening national unity and integrity, maintaining and implementing Pancasila [3]. As stated by Lemhanas, the spirit of nationalism that must be possessed by the younger generation in this case is the students, namely "the spirit of togetherness to build a more prosperous future for all Indonesian citizens, regardless of ethnicity, religion, race, skin color, gender or class" [24]

According to Rajasa (2007) that the younger generation can develop the character of nationalism through three processes, namely: First, character building, which means that the younger generation must have a strong will to build the positive character of the nation, to uphold the moral values of Pancasila and apply them in life. real; The second is character enabler, where the young generation becomes a role mode for the development of a positive national character by building positive awareness with high cohesiveness, such as mediating in a conflict resolution; and Third, character engineers mean that the younger generation must play a role by achieving in science and culture and technology, as well as being involved in the learning process in developing the positive character of the nation according to the times [25].

From this concept, we can conclude that the role of the younger generation is very important, because youth as a pillar of civilization in the future, the noble values contained in Pancasila must be completely absorbed by the youth and can be applied in everyday life. Pancasila plays a very important role in fostering a sense of nationalism in the younger generation, provided that the younger generation is willing to inspire and internalize these values, so that they are able to filter out the rapid flow of information and outside cultures that are contrary to the values of the Indonesian nation's ideology, namely Pancasila. Thus, the youth will be able to sort out the incoming foreign culture without forgetting their own culture.

\subsection{Our Contribution}

This paper presents how Pancasila is the state ideology in shaping the nationalism of the younger generation. This paper also examines Indonesian nationalism which is different from western nationalism and the relationship between nationalism and the principles of Pancasila which must be internalized by the younger generation in order to maintain the unity of Indonesia as a multicultural country.

\subsection{Paper Structure}

The rest of the paper is organized as follows. Part 1 introduces the background of the writing of this paper, the author sees the decline in the nationalism of the younger generation as a result of the uncontrolled flow of globalization. Section 2 presents the methods used in the process of compiling results and discussions. Next is Part 3 of the results which contains findings and a discussion of how Pancasila as an ideology is able to provide solutions to form nationalism in Indonesia's young generation. and finally in Section 4 concludes the paper and provides guidance for future research.

\section{CONCLUSION}

Pancasila is one of the open ideologies in the world that has advantages over other ideologies. This is because Pancasila philosophically contains noble values from the 
Indonesian state, values that are formed through the long history of this country in the face of colonialism and colonialism, as an open ideology Pancasila is able to accommodate all the problems that exist in Indonesia, especially the problems of the younger generation. In the era of the industrial revolution 4.0. Every point of Pancasila has a deep meaning if it is really lived up to by the younger generation, if we instill the Pancasila ideology from an early age through Citizenship Education it becomes a preventive solution to the negative influences from outside culture. A persuasive approach and discussion also needs to be carried out with the younger generation in order to internalize the values of Pancasila, so that the sense of nationalism of the younger generation is maintained from the past to the present and in the future.

\section{ACKNOWLEDGMENT}

This article is supported by Nurilah who has provided suggestions and recommendation so that the authoress can complete this article. Then, the authors also convey to the committee The International Conference on Character Education (ICCE) University of Muhammadiyah Semarang as a reviewer of this article.

\section{REFERENCES}

[1] Setyowati, P. J. (2016). Fungsi Filsafat, Agama, Ideologi Dan Hukum Dalam Perkembangan Politik Di Indonesia. Yuridika, 31(1), 37. https://doi.org/10.20473 /ydk.v31i1.1957

[2] Jimly, A. (2006). Ideologi, Pancasila, dan konstitusi. Jaringan Informasi Hukum, (1), 1-23. Retrieved from jdih.ristekdikti.go.id/?q=system/files/perundangan/1927 202140.pdf\%0A

[3] Undang Undang Nomor 40 Tahun 2009 Tentang Kepemudaan

[4] Gunawan, (2017). https://jogja.tribunnews.com 12017/06/01/banyak-generasi-muda-tak-hapal-pancasila -lambang-garuda-juga-jarang-terlihat-terpasang.

[5] Lesmana \& Arandito, (2019). https://www.suara. com/news/2019/07/16/113931/banyak-warga-indonesia -tak-hafal-pancasila-terparah-bangka-belitung

[6] Gunandha, (2017). https://www.suara.com/news /2017/09/27/024408/survei-separuh-warga-indonesia-ta k-hafal-lagu-indonesia-raya
[7] N.N. (2006). Diakses https://news.detik.com/berita 1653718/80--anak-sekolah-tidak-hafal-lagu-indonesia-ra ya

[8] Kyridis, A., Mavrikou, A., Zagkos, C., Golia, P., Vamvakidou, I., \& Fotopoulos, N. (2009). Nationalism through state-constructed symbols: The case of national anthems. International Journal of Interdisciplinary Social Sciences, 4(6), 1-13. https://doi.org/10.18848/1 833-1882/CGP/v04i06/52940

[9] Sundawa, D. (2017). Penguatan Karakter Mahasiswa Yang Berwawasan Kebangsaan dalam Menghadapi Tantangan Disintegrasi Bangsa. Prosiding Seminar Nasional Tahunan Fakultas Ilmu Sosial Universitas Negeri Medan Tahun 2017 Vol. 1 No. 1 2017, Hal. 202-205. http://semnastafis.unimed.ac.id.

[10] Winarno. (2007). Paradigma Baru Pendidikan Kewarganegaraan Panduan Kuliah di Perguruan Tinggi. Surakarta: PT. Bumi Aksara.

[11] Creswell, J. (2015). Riset Pendidikan : Perencanaan, Pelaksanaan, dan Evaluasi Riset Kualitatif \& Kuantitatif. Yogyakarta: Pustaka Pelajar.

[12] Prabowo A. \&Heriyanto, (2013). Analisis Pemanfaatan Buku Elektronik (E-Book) Oleh Pemustaka di Perpustakaan SMA Negeri 1 Semarang. JURNAL ILMU PERPUSTAKAAN Volume 2, Nomor 2, Tahun 2013 Halaman 1-9

[13] Fossati, D., Aspinall, E., Muhtadi, B., \& Warburton, E. (2020). Ideological representation in clientelistic democracies: The Indonesian case. Electoral Studies, 63 (July 2019), 102111. https://doi.org/10.1016/j.electstud.2019.102111

[14] Juneman, Meinarno, E. A., \& Rahardjo, W. (2012). Symbolic Meaning of Money, Self-esteem, and Identification with Pancasila Values. Procedia - Social and Behavioral Sciences, 65(ICIBSoS), 106-115. https://doi.org/10.1016/j.sbspro.2012.11.099

[15] Sudaryanti, D., Sukoharsono, E. G., Baridwan, Z., \& Mulawarman, A. D. (2015). Critical Analysis on Accounting Information Based On Pancasila Value. Procedia - Social and Behavioral Sciences, 172, 533539. https://doi.org/10.1016/j.sbspro.2015.01.399

[16] Huda, M.C. (2018). Meneguhkan Pancasila Sebagai Ideologi Bernegara: Implemetasi Nilai-Nilai Keseimbangan dalam Upaya Pembangunan Hukum di Indonesia. Resolusi: Jurnal Sosial Politik, 1(1), 78-99. https://doi.org/https://doi.org/10.2489/resolusi.v1i1.160 
[17] Maulia, S. T. (2011). Pemahaman Konsep NilaiNilai Pancasila Sebagai Ideologi Bangsa, 46-55. SEMINAR NASIONAL : Aktualisasi Nilai-nilai Pancasila di Era Reformasi ISSN: 2598-6384

[18] Riyanto, A. (2007). Pancasila Dasar Negara Indonesia. Jurnal Hukum \& Pembangunan, 37(3), 457. https://doi.org/10.21143/jhp.vol37.no3.151

[19] Sundawa, D. (2016). Fostering Democratic Intelligence of Young Citizens Through the Implementation of Civic Education Classroom as Democratic Laboratory, 55-62. https://doi.org/10.2991 licse-15.2016.12

[20] Sitorus, J. H. E. (2016). Pancasila-based Social Responsibility Accounting. Procedia - Social and Behavioral Sciences, 219, 700-709. https://doi.org/10. 1016/j.sbspro.2016.05.054

[21] Meinarno, E. A., \& Mashoedi, S. F. (2016). Pembuktian Kekuatan Hubungan Antara Nilai-Nilai Pancasila Dengan Kewarganegaraan. Jurnal Ilmiah Pendidikan Pancasila Dan Kewarganegaraan, 1(1), 12-22. https://doi.org/10.17977/um019v1i12016p012

[22] Miftahuddin, M. (2015). Nasionalisme Indonesia: Nasionalisme Pancasila. MOZAIK: Jurnal Ilmu-Ilmu Sosial Dan Humaniora, 4(1), 1-20. https://doi.org/10. 21831/moz.v4i1.4386

[23] Latief et al. (2015). Nasionalisme: Modul Pendidikan dan Pelatihan Prajabatan Golongan III. Jakarta: Lembaga Administrasi Negara.

[24] Sofyan, F.,S., dan Sundawa, D. (2015). Hubungan Mata Kuliah Pendidikan Kewarganegaraan dengan Peningkatan Wawasan Kebangsaan dan Semangat Nasionalisme Mahasiswa. JPIS. Jurnal Pendidikan Ilmu Sosial, Vol. 24, No. 2, Edisi Desember 2015. DOI: https://doi.org/10.17509/jpis.v24i2.1455.

[25] Ginting, H. (2017). Peranan Pancasila Dalam Menumbuhkan Karakter Bangsa Pada Generasi Muda. Prosiding Seminar Nasional Tahunan Fakultas Ilmu Sosial Universitas Negeri Medan, 1(1), 197-201. Retrieved from heryansyahginting@gmail.com 